\title{
Gelezen
}

\section{Onze hersenen: onze achtbaan}

\author{
Jo A. M. Vandermeulen
}

Dawson Hedges, Thoma J. Farrer, Erin D. Bigler, Ramona O. Hopkins - The brain at risk (Associations between diseases and cognition) - Springer Verlag, Switzerland, 2020. ISBN 978-3-030-14260-5.

Een achtbaan lijkt het wel, dit boek. Al lezend raas je van het ene onderwerp naar het andere, waarbij de thema's elkaar afwisselen en je voortdurend moet switchen. Belangrijke onderwerpen die binnen de neuropsychologie een rol spelen, passeren de revue. Deze hoofdthema's worden inhoudelijk divers uitgewerkt. Het is zo veel dat het eigenlijk moeilijk wordt om ieder thema afzonderlijk te bespreken. Men hanteert binnen de thema's in ieder hoofdstuk dezelfde opbouw.

Het boek omvat 18 themagerichte hoofdstukken, een inleidend hoofdstuk en een samenvattend hoofdstuk aan het eind. Het inleidende hoofdstuk belicht de complexiteit van onze hersenen. De auteurs beschrijven de diverse stadia die voortvloeien uit de cellulaire ontwikkeling en de risico's die kunnen ontstaan tijdens de levensloop (geboorte, neonatus, eerste levensjaren, schoolgaande periode, volwassenheid en ouderdom). Het is in die zin relevant, omdat het een algehele samenvatting geeft van alle processen die tijdens de ontwikkeling van de hersenen een rol spelen en wat de invloed is van interne en externe positieve en negatieve factoren op het centrale en autonome zenuwstelsel; men heeft dat praktisch en duidelijk overzichtelijk uitgewerkt.

Een bijkomstige handigheid is dat, als je het boek als pdf-bestand koopt, er bij ieder hoofdstuk een icoontje staat dat verwijst naar een update van het betreffende

J. A. M. Vandermeulen $(\bowtie)$

Koninklijke Visio, Geleen/Sittard, Nederland

e-mail:jovandermeulen@visio.org hoofdstuk, of naar een artikel dat aanvullende informatie oplevert. Dat geldt ook voor de plaatjes die ondersteund worden door een doi.org code. Als je daarop klikt, krijg je extra informatie over het gebruikte artikel of de beschrijving van de figuur. Voordeel: het verstrekt je extra achtergrondinformatie die relevant kan zijn.

Er zijn 16 kernhoofdstukken. Deze betreffen de vaak voorkomende problematieken waarbij neuropsychologisch onderzoek een waardevolle bijdrage kan leveren. In Nederland is daar voor de psychotherapeuten al een belangrijke aanzet voor geleverd [1], maar in dit boek komen meer thema's aan de orde.

Alle hoofdstukken kennen een nagenoeg identieke opbouw, bestaande uit de volgende kaders: taal, leren en geheugen, aandacht, verwerkingssnelheid, executieve functies, visueel-spatiële waarneming, oorzaken, etiologie en conclusie (met uitzondering van eetstoornissen - daarbij is er alleen aandacht voor de mechanismen die een rol spelen). Hoofdstuk achttien is samenvattend van aard en richt zich op de toekomstige ontwikkelingen, waaronder de impact van kunstmatige intelligentie en het gebruik van robots in het kader van diagnostiek en behandeling. Dit laatste hoofdstuk tracht inzicht te geven in kwetsbaarheid en veerkracht van de hersenen. Het doel van de auteurs is te laten zien hoe genen en omgeving met elkaar zijn versmolten, maar ook willen ze de invloeden aanreiken van de ontwikkelingsneuropsychologische aspecten, en van omgevings- en mitigerende factoren, rekening houdend met het feit dat alle hersenen anders zijn in opbouw en structuur. Je kunt een dergelijk ontwikkelingsneuropsychologisch model ook vinden bij Anderson en collega's [2], maar dat model is vooral gericht op het kind en de jeugdzorg. 
De volgende thema's, die voortvloeien uit de praktijk, worden conform de boekindeling besproken:

1. affectieve stoornissen: depressieve stoornissen en bipolaire stoornissen;

2. angsten: generaliserende angststoornis, paniek en sociale angststoornis;

3. aandachtstekortstoornis en hyperactiviteit;

4. schizofrenie;

5. cerebrovasculaire accident: vasculaire dementie, beperkte en uitgebreide

6. neurocognitieve stoornis en wittestofproblematiek;

7. anorexia nervosa en boulimie;

8. endocriene aandoeningen: hypofyse, lever, pancreas, schildklier en diabetes mellitus;

9. chronische pijn: migraine, traumatisch hersenletsel, rugpijn, medicatie en pijn en

10. fibromyalgie, complexe regiogebonden pijnsyndromen (CRPS) en de invloed van opiaten;

11. sepsis ${ }^{1}$, postintensivecaresyndroom (PICS), dementie, angst, depressie en de invloed van ontstekingen;

12. postoperatieve cognitieve stoornis (POCS): delirium, hartchirurgie, transplantaties, ontstekingen en anesthesie;

13. multipele sclerose: Epstein-Barr-virus, ziekte van Pfeifer;

14. traumatisch hersenletsel: contusio cerebri, commotio cerebri, bewustzijnsverlies, amnesieën;

15. drugs, antidepressiva, anxiolytica, psychoanalytica (cannabis, cocaïne, benzodiazepinen) en anticholinergica;

16. obstructieveslaapapneusyndroom (OSAS): hypoxie, stress en wittestofproblematiek;

17. koolmonoxidevergiftigingen;

18. pulmonale aandoeningen: acute respiratoire distress syndroom (ARDS) en COPD, astma en dementie.

In dit boek wordt een holistische benadering gebruikt, die steeds meer opgeld doet $[1,2]$. Het doel van het boek is volgens de auteurs:

$\therefore$ The brain is at risk with seemingly insurmountable odds stacked against it and doomed to fail at some point, because of its complexity and interdependence of multifaceted and intricate neural systems. That is not what we want to convey, quite the opposite in fact. What we have attempted in this book is to provide a better under-

1 Een sepsis is een reactie van het lichaam op een infectie. Een infectie kan veroorzaakt worden door micro-organismen of ziekteverwekkers, zoals bacteriën, virussen, schimmels, gisten of parasieten. Als de ziekteverwekkers in de bloedbaan komen, wordt dit een bloedvergiftiging of sepsis genoemd met vaak allerlei fysieke aandoeningen. standing of some myriad factors involving in brain health and how an understanding of injuries and pathologies may modify or avoid some of the factors involved with the cognitive outcomes...' (pag. 276).

Zijn de auteurs daarin geslaagd? Het boek geeft een heel goed overzicht van de recente stand van zaken ten aanzien van de vermelde thema's. In Nederland is bij mijn weten geen publicatie bekend die hier minutieus aandacht aan besteedt.

Is er relevante kritiek op het boek te leveren? Zeker wel: het boek leest niet echt prettig, er staan te veel literatuurverwijzingen in en eigenlijk vormt het geen samenhangend geheel.

Het hoofdstuk dat is gericht op ADHD is niet echt vernieuwend; ADHD is een vaak besproken thema dat in allerlei handboeken inhoudelijk goed is uitgewerkt. Ik denk dat het handboek van Barkley [3] daar eerder recht aan doet en dit boek van Brown [4].

Het hoofdstuk over sepsis sluit aan bij de huidige problematiek van COVID-19. Veel mensen met COVID-19 die langere tijd zijn behandeld op een intensive care hebben aandoeningen die passen in dit thema, afgezien van het feit dat er per jaar ongeveer 10 miljoen mensen sterven aan de gevolgen van sepsis [5]. Over de neuropsychologische aspecten van PICS is reeds meer bekend dan in het boek wordt beschreven, die mogelijk ook waardevol zijn voor de posttraumatische gevolgen van COVID-19. Het betreft dan lichamelijke, cognitieve en psychische gevolgen en afname van kwaliteit van leven [6].

De impact van deze gevolgen gelden ook voor POCS, een stoornis die vaak voorkomt bij ouderen na een operatie en gepaard kan gaan met onder andere een delirium. Dit geldt eveneens voor pulmonale aandoeningen (ook gerelateerd aan COVID-19). In de Nederlandstalige literatuur zijn de gevolgen van pulmonale aandoeningen niet vaak vermeld in het licht van neuropsychologische stoornissen, vandaar dat ik het een verrijking vind dat dit thema opgenomen is in het boek. De informatie kan zeker ondersteunend werken bij het opzetten van een revalidatieplan voor behandeling en nazorg. Zie ook www.fcic.nl.

Over het algemeen kan worden geconcludeerd dat de neuropsychologische problematiek die in de afzonderlijke hoofdstukken wordt besproken inhoudelijk goed is weergegeven, maar je krijgt niet het gevoel dat het verinnerlijkt: door de grote hoeveelheid aan informatie per hoofdstuk mis je overzicht en dat gaat ten koste van de verbeelding. Men reikt constant nieuwe onderzoeken aan om de inhoud van een hoofdstuk te bevestigen, wat de leesbaarheid niet ten goede komt. Je raakt de leeslijn kwijt, wat het enthousiasme over het boek dan weer tempert. Het boek moet dan ook eerder als een naslagwerk worden beschouwd, dat wel goed geschreven en gedocumenteerd is. Zeker als je het als pdf-bestand koopt en toegang krijgt tot de extra 
informatie. Dat geldt ook voor het ontwikkelingsneuropsychologisch model dat de auteurs hanteren, dat de kern van dit boek weergeeft. Het is best behulpzaam, maar ik heb stellig de indruk dat men het pas zal lezen als men met het thema in aanraking komt.

Rest ons eigenlijk nog de eindconclusie: aanschaffen, ja, maar dan vooral als naslag- en overzichtswerk.
Het is voor de praktijk waardevol als je een gevorderde lezer bent binnen het vakgebied van de neuropsychologie, om zicht te krijgen op deze materie. Vanuit die invalshoek is het boek dan weer géén achtbaan, maar werkt het als een gestroomlijnd geslaagd naslagwerk.

\section{Literatuur}

1. Vandermeulen JAM, Derix MMA, Dijke A van. De rol van neuropsychologie bij psychotherapie. Houten: Bohn, Stafleu van Loghum; 2019.

2. Anderson V, Northam E, Wrennall J. Developmental neuropsychology (a clinical approach). 2e druk. Londen: Routledge; 2019.

3. Barkley RA. Attention deficit hyperactivity disorder. 4e druk. New York: Guilford; 2018.

4. Brown TE. Outside the box: rethinking ADD/ADHD in children and adults. Washington: American Psychiatric Publishing; 2017.

5. Rudd KE, Johnson SC, Agesa KM, Shackelford KA, Tsoi D, Kieflan DR, et al. Global, regional, and nati- onal sepsis incidence and mortality, 1990-2017: analysis for the Global Burden of Disease Study. Lancet. 2020;395(10219):200-11.

6. Wenting A, Griters A, Os Y van, Verstraeten S, Valentijn S. Medisch psychologische nazorg van COVID-19. Psycholoog. 2020;7:50.

Jo A.M. Vandermeulen klinisch psycholoog, klinisch neuropsycholoog kwaliteitsregister psychotherapeuten 